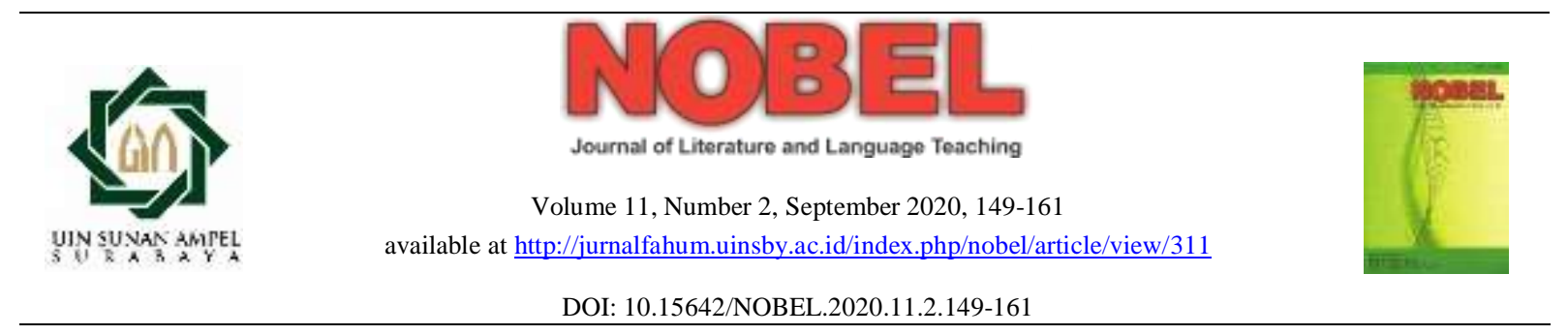

\title{
AN INVESTIGATION OF MACROSTRUCTURE, SUPERSTRUCTURE, AND MICROSTRUCTURE ON ONLINE NEWS TEXT
}

\section{Muhammad Faishol Nurul Huda ${ }^{1}$, Didin Nuruddin Hidayat ${ }^{2 \bowtie}$, Alek $^{3}$}

Universitas Islam Negeri Syarif Hidayatullah, Jl. Ir H. Juanda No.95, Ciputat, Banten, Jakarta, Indonesia

\begin{tabular}{l}
\hline Article Info \\
\hline Article History: \\
Received July 2020 \\
Accepted August 2020 \\
Published September 2020 \\
\hline Keywords: \\
critical discourse analysis, \\
linguistics, relocating of the \\
capital city, tempo.com \\
\hline
\end{tabular}

\section{Abstract}

This study aimed to analyze the structure of the text in the news texts of tempo.com entitled "Tolak Relokasi Ibu Kota," published in 2019, in which it highlighted the government's plan to relocate the capital city of Indonesia. The descriptive qualitative model was used by adapting van Dijk's approach. The data were analyzed only in terms of the structure of text on online media tempo.com and with the orientation of the descriptive-analytic method. The data of this study were presented qualitatively. The results showed that the journalists of tempo.com media built public opinion in the news negatively. The journalists utilized selected diction, cause-effect organization, and selected speaker's indirect quotations to produce news texts. Besides, the news was considered in harmony with its mission of providing a multimedia product independent and free from all pressures. The readers were led to a negative image of the government on tempo.com as an active and existent media in voicing justice. 


\section{INTRODUCTION}

In recent years, news discourse has become one of the leading research areas in Critical Discourse Analysis (CDA). CDA itself is an effort or process of explaining a text studied by a person or dominant group whose tendency has a certain goal to get something desired. Therefore, CDA provides a challenge for readers to understand a text that brings us to a high level of understanding and digs a clear explanation of the reasons and purpose of the text being formed (Hidayah \& Hidayat, 2019). However, discourse analysis formed in the mass media, whether we realize it or not, is influenced by journalists or authors from various factors. Besides, it is necessary to realize that behind the discourse in the mass media, there is the meaning and image desired and the interests to fight. Helfer (2016) states that the media plays a significant role in political issues and determining the political agenda. Accordingly, the media play a crucial role in how politics is formed, and media considerations are an essential factor in ascertaining what issues will be raised.

Particularly in language learning, media are reported to be useful for learning sources since the learning must always relate to real life and society. Media provide authentic language learning materials for students. Also, learning media is a tool to convey information from the author to the reader, and therefore, the pieces of information can be well-conveyed (Setiawan, 2016). When the information provided in media is used as language learning materials, language learners, as media users, must understand how journalists technically construct the text in the news to reflect certain attitudes, whether it is political or personal. Therefore, understanding the journalists' attitudes concerning specific texts is essential for second language learners because they may not have the background to interpret the text in its historical context. In reflecting on a certain attitude, the first thing that media users need to do is understanding how journalists technically construct the texts.

To understand how journalists technically construct the text, CDA is widely used to investigate the relationship between news and social and political language. According to Hasanah et al. (2019), CDA attempts to examine the language conveyed in either the context of social or political dimensions and explores the connections of the power embedded through the language. CDA is characterized by five principles: action, context, history, power, and ideology (Eriyanto, 2001; Fairclough, 1995b; Fitriana et al., 2019). Within the characteristics of action, there are two consequences in observing discourse. First, discourse is seen as something that aims to influence, deny, debate, react, and persuade. Second, discourse is understood as something that is expressed consciously or controlled. For instance, Fathan (2018) noted that media users can expose abuse of power, domination, and injustice done and 
produced inappropriately through news texts. In media, fact is presented by the journalist's judgment. The journalist's judgment is shaped from the perspective of the journalist in expressing an event. Hence, facts could seem otherwise because it relies on the understanding and characteristics of every journalist.

In recent years, there have been significant studies that addressed critical discourse analysis within political issues. For instance, Supriyadi and Zulaeha (2017) conducted a study to uncover the political, economic, and ideological dimensions found in the Jawa Pos. This study employed Bogdan and Biklen's theory to uncover the economic, political, and ideological dimensions. The results showed that (a) the political economy of media in studies was widely used to study the economy, politics, and ideology in the CDA perspective, (b) as a construction, mass media, in this case, the Jawa Pos often represents certain economic, political and ideological interests, (c) analysis of critical discourse became one of the essential models for analyzing the linkages between reality, economics, politics, and ideology in sequence, and the interdisciplinary scientific combination between critical theory, critical linguistic theory, and (d) political economy theory is used to analyze how economic, political and ideological interests play a role in media publishing, including the mass media, in this case, the Jawa Pos print media.

Furthermore, Assidik and Santoso (2016), employing Fairclough's CDA, investigated how President Joko Widodo is portrayed in three national newspapers, Suara Merdeka, Republika, and Kompas Tabloid. The results showed that (a) Suara Merdeka and Republika newspaper lead to the positive image information for the President, while Tabloid Tempo incline to the negative image formation for the President, (b) discourse practice analysis is focused on how texts are produced and consumed, (c) news texts produced by media promote texts, discourse practices, and socio-cultural practices. Hence, a textual analysis plays a role in investigating how the mass media portrays the President.

Even though CDA was widely explored within the political discourse and printed media, there is little evidence that such a study was conducted in online media. Therefore, this study aims to fill in the gaps in online media within political discourse. Through online media, people can easily access information from both domestic home affairs and abroad. Whatever information people need will be easily and quickly accessed without the need for expensive costs. Online media offers a communication opportunity that can penetrate time and space. Journalism requires the media to become a forum for disseminating information published in the news. Various information and news became the hottest talks from all directions, which can be accessed with the power of online media. This online media can provide ample benefits 
for human life, including the journalism world (Nuraeni, 2017). This present research employed van Dijk's theory to explore the structure of the tempo.com news texts about relocating the capital city. Van Dijk (2008) classified the analysis technique into three dimensions of analysis; they are social cognition, the structure of the text, and social analysis. Social cognition involves a person scheme, self-scheme, role scheme, and event schema. The structure of the text involves macrostructure (thematic), superstructure (schematic), and microstructure (semantic, syntax, stylistic, and rhetoric). The social analysis involves power practice and access to influence discourse. Based on the background that has been described, the present study analyzed macrostructure analysis, superstructure analysis, and analysis of microstructures in online news tempo.com.

\section{REVIEW OF LITERATURE}

\section{A Discourse Analysis of Teun A. Van Dijk}

Many experts have introduced and developed various models of discourse analysis (e.g., Fairclough, 1995; Kendall, 2007; Leeuwen, 2008; Mills, 1992; van Dijk, 2008). van Dijk's model is the most popular and widely used model of discourse analysis, in which he may have the most practical elements.

According to van Dijk (2008), research on discourse based on analysis of the text alone is not enough, because the text is only the result of a production practice that must also be observed. Here, we must also look at how a text is produced to understand why a text can be like that. Through his various works, van Dijk created an analytical framework discourse that can be utilized, and he sees multiple structures/levels, each part supporting each other. He divided it into three levels: mutually interlocking support such as social cognition, the structure of the text, and social analysis. Furthermore, van Dijk sees a text consisting of several text structures or levels, each of which supports one another. He divided it into three levels of text structure: macrostructure, superstructure, and microstructure. In macrostructure, the thematic elements are the global meaning of discourse and also generally describes the theme of discourse on each news topic in which there are essential points that refer back to the central theme. In superstructure, text or discourse generally has a flow scheme from the introduction to the end. The flow shows how the parts in the text are arranged and ordered to form a unified meaning. A story consists of two schemes. The first summary is marked with the title and lead. Then the second is the story, which is the entire news content. Lastly, the 
microstructure consists of semantic analysis, syntax analysis, lexicon analysis, and stylistic. Here, the brief explanation is as follows:

Table 1. van Dick's Elements of Discourse

\begin{tabular}{lll}
\hline Discourse structure & Observe element & Element \\
\hline Macrostructure & Thematic: Theme or topic that is developed in a text & topic \\
\hline Superstructure & Schematic: How the structure of text schemes & scheme \\
\hline Microstructure & $\begin{array}{l}\text { Semantics: Meaning intended in the text such as } \\
\text { giving detail or explicit in a side and reducing } \\
\text { another side }\end{array}$ & $\begin{array}{l}\text { background, detail, intention, } \\
\text { presupposition }\end{array}$ \\
\cline { 2 - 3 } & $\begin{array}{ll}\text { Syntax: Form of sentenced chosen } \\
\text { fexicon: Word choice used in the text }\end{array}$ & $\begin{array}{l}\text { coherency, pronoun } \\
\text { conicon }\end{array}$ \\
\cline { 2 - 3 } & Stylistic (rhetoric): How meaning is intended in a text & figure/graphic, metaphor \\
\hline
\end{tabular}

Source: (Eriyanto, 2001, p. 299)

\section{METHOD}

The study employed a descriptive qualitative research method. It aimed to describe structures of the text entitled "Tolak Relokasi Ibu Kota" in online news tempo.com published on August 19, 2019, by adapting van Dijk's (2008) approach. Descriptive data is the data that is collected in the form of words, pictures, and not numbers. Therefore, the study report contains data quotations to illustrate the report related to people's words and behavior. The description becomes a vital thing to get a clear description and understanding of the problem being discussed. Also, the interpretation process is carried out to interpret the data to reveal its meanings as part of the analysis. The data were gained in the form of written texts of the online news.

For collecting the data, four steps were adapted from O'Connor and Gibson (2017). First, the researchers read over the written text about "Tolak Relokasi Ibu Kota" on the tempo.com website. Next, the researchers marked the underlying aspect of the structure of the text in the data. Finally, the researchers coded and categorized the data. Fourth, the researchers interpreted the data. A CDA model proposed by van Dijk on the structure of the text was employed to figure out the macrostructure, superstructure, and microstructure in the online news. Finally, the results of this study are expected to give an academic contribution to research related to online media. It is also expected that the results of this study provide an advantage for information, references, and comparison of CDA study on media with various topics within the context of online media reporting. 


\section{RESULTS AND DISCUSSIONS}

Referring to the classification of structural text and social context proposed by van Dijk (2008), the researchers classified the text in tempo.com into the following categories:

\section{The Analysis Structure of Text}

\section{Macrostructure}

The analysis structure of the text within macrostructure or thematic specifically looked at the common background or core idea or topic in news media. The macrostructure of tempo.com is presented on the following table:

\section{Table 2. Macrostructure (Thematic)}

\begin{tabular}{|c|c|c|}
\hline Theme/Topic & Sub-theme & Findings \\
\hline $\begin{array}{l}\text { Relocating the } \\
\text { Capital City }\end{array}$ & $\begin{array}{l}\text { Building public } \\
\text { opinion to deny the } \\
\text { relocation of the } \\
\text { capital city }\end{array}$ & $\begin{array}{l}\text { - Indonesia Parliament should not support the relocation of } \\
\text { the capital city, Jakarta, to Kalimantan. Relocating the } \\
\text { capital city is not a good way to solve the problem of } \\
\text { development planning equity, economic justice, and also } \\
\text { not an effective way to solve the environmental problem in } \\
\text { Jakarta. (Paragraph 1) } \\
\text { The relocation plan must not be denied since this step is not } \\
\text { a good solution for development planning equity and } \\
\text { economic justice. However, we have problems both of them } \\
\text { for the fastest relocation will just advance the development } \\
\text { planning in the new capital city. (Paragraph 4) }\end{array}$ \\
\hline
\end{tabular}

Referring to van Djik's theory, thematic is the global meaning of discourse. The theme is a common description of what people's opinion is said. Based on the data in table 2, the researcher found that the main theme was "Relocating the Capital City." The selection of the title or topic from tempo.com represents the information on indications to build public opinion against the government's will to relocate the capital city of Indonesia. In supporting its main theme, the journalist placed sub-topics in the news sentence in paragraph 4 , which the journalist suggested the government doing economic equality than relocating the capital city.

\section{Superstructure}

The superstructure or schematic emphasizes which part comes first and a strategy to hide important information later. A discourse commonly has schematic from the beginning till the end. The steps of the schematic are presented in table 3: 
Table 3. Superstructure (Schematic)

\begin{tabular}{|c|c|c|}
\hline Title & Lead & Story \\
\hline $\begin{array}{l}\text { Relocating } \\
\text { the Capital } \\
\text { City }\end{array}$ & $\begin{array}{l}\text { Relocating the capital city is not a } \\
\text { good way to solve the problem } \\
\text { development planning equity, } \\
\text { economic justice, and also not an } \\
\text { effective way to solve the } \\
\text { environmental problem in } \\
\text { Jakarta. (Paragraph 1) }\end{array}$ & $\begin{array}{l}\text { - The first flow that tempo.com gave was in paragraph } \\
\text { 1. It said that Indonesia Parliament should not support } \\
\text { relocating the capital city, Jakarta, to Kalimantan. } \\
\text { In paragraph 4, "Relocation plan must not be denied } \\
\text { since this step is not a good solution for development } \\
\text { planning equity and economic justice." Next } \\
\text { paragraph, build public opinion against the } \\
\text { government's plan to relocate Capital City. } \\
\text { In the last paragraph, paragraph 8, "President Joko } \\
\text { Widodo had better utilized the second period of his } \\
\text { leadership to solve economic problems, improve } \\
\text { public services, decrease inequality, and eradicate } \\
\text { corruption." }\end{array}$ \\
\hline
\end{tabular}

Based on van Dijk's theory, the schematic meaning is the journalist's strategy to support certain topics conveyed in a certain flow since schematic flow shows how a part of the text is made and arranged. From the data presented in table 3, we can see that as a starting point in the first paragraph, the journalists proposed to the House of Representatives (DPR) not to support the plan to relocate the capital city. In paragraph 4, the journalists tried to build public opinion to reject the plan by shifting the readers' attention to the existing urgent problems that need to be addressed. Interestingly, the journalists also directly mentioned that the President (Joko Widodo) had better prioritize the programs in his second period to improve Indonesia's economy, improve the public service, reduce social inequality, and eradicate corruption (paragraph 8). This schematic flow from DPR to the President was arranged by the journalist because DPR has the authority to accept or deny the government's plan about the relocation of the capital city.

\section{Microstructure}

The microstructure is related to the choice of words made by the journalists in using the sentences in his messages, such as the use of sentence forms, pronouns, and coherence. 


\section{Table 4. Microstructure analysis}

\begin{tabular}{|c|c|}
\hline Semantics & Findings \\
\hline Background & $\begin{array}{l}\text { Tempo mentioned that the relocation of the capital city from Jakarta to Kalimantan } \\
\text { is not an excellent way to solve the problem of equitable development and } \\
\text { economic justice; therefore, it should be rejected. }\end{array}$ \\
\hline Details & $\begin{array}{l}\text { Journalists of tempo.com gave some reasons why relocating the capital city should } \\
\text { be rejected. }\end{array}$ \\
\hline Aim & $\begin{array}{l}\text { The contents of the news from tempo.com can be seen clearly by the side of } \\
\text { journalists or editors who published news related to "Refuse of Relocating Capital } \\
\text { City. Journalists of tempo.com build public opinion on the reasons for not agreeing } \\
\text { to the government's plan in relocating the capital city }\end{array}$ \\
\hline Presupposition & Relocating the capital city is not a good way. \\
\hline Syntactic & Findings \\
\hline Sentence Forms & $\begin{array}{l}\text { Inductive form (the paragraph in which the main thoughts are at the beginning of } \\
\text { the paragraph). In other words, the main topic of the news is described at the } \\
\text { beginning of the paragraph. }\end{array}$ \\
\hline Coherence & $\begin{array}{l}\text { The matter of relocating the capital city will indeed involve the House of } \\
\text { Representatives (DPR). Besides the budget issues and the issuance of various new } \\
\text { laws, there are at least nine laws that must be changed. For instance, Law Number } \\
29 \text {, Year } 2007 \text { concerning DKI Jakarta, Regional Government Law, Spatial } \\
\text { Planning Law, and Environmental Law. Although, these are not the only things } \\
\text { that make the relocation plan for the capital city unrealistic. (Paragraph 3) }\end{array}$ \\
\hline Pronouns & $\begin{array}{l}\text { However, we have problems both of them for the fastest relocation will just } \\
\text { advance the development planning in the new capital city. (Paragraph } 4 \text { ) }\end{array}$ \\
\hline Stylistic & Findings \\
\hline Lexicon & $\begin{array}{l}\text { Title: Relocating Capital City } \\
\text { Relocating the capital city is not a good way to solve the problem of development } \\
\text { planning equity, economic justice. It is not an effective way to solve the } \\
\text { environmental problem in Jakarta as well. (Paragraph 1) }\end{array}$ \\
\hline Rhetorical & Findings \\
\hline $\begin{array}{l}\text { Graphic } \\
\text { Metaphor }\end{array}$ & $\begin{array}{l}\text { In the news, Jokowi \& Jusuf Kalla's photos were shown on the news. } \\
\text { The title was designed large that the content }\end{array}$ \\
\hline
\end{tabular}

Based on the semantics of the elements in Table 4, it appears that the journalists of tempo.com were consistent with the topic "Refuse the Capital Relocation," where the contents of the news built the opinion of the public. The opinion of the public was directed to provide a negative image of the government's plan. In syntactic elements based on the sentence forms in terms of coherence, the journalists used a connecting word "besides" mentioning budget issues and the changes in various laws to support the relocating of the capital city. In terms of pronoun, the journalists used "we" in paragraph 4. It means that the journalists positioned themselves as the victim so the reader will think negatively of the government.

Furthermore, in terms of stylistic, the journalists utilize the phrase "cara jitu" in paragraph 1. The phrase equals meaning to 'right on target.' In terms of graphics, the journalists or editors showed Jokowi and Jusuf Kalla's picture. It means that the journalists or editor wants to remind the readers instead of the National Monument (Monas) as the icon of Jakarta. In terms of metaphor, the journalists also have written the title of the news in bold. It means that the journalists wanted to remind the reader instated of the urgency condition. 
This study focuses on the structure of the news text from online media tempo.com analyzed based on van Dijk's theory of three levels of text structure: macrostructure, superstructure, and microstructure. The macrostructure analysis used to understand the global meaning of the text published by tempo.com was an argumentation and description that tend to persuade and invite readers not to support the government's plans to relocate the capital city. In contrast to this study, Rahzanie and Rustono (2019) found that Suara Merdeka tended to give support and a positive image to the readers that the government and the police had worked together nicely to fight against terrorism.

The superstructure level was constructed with a narrative style. The chronological sequence of each event was structured to construct a cohesive text addressing relocating the capital city. As a starting point in the first paragraph, the journalists proposed to Indonesia Parliament not to support the plan to relocate the capital city. In the fourth paragraph, the journalists continued that the relocation plan must be rejected since this step is not a good solution for an equitable development plan and economic justice. Furthermore, the journalists, in the eighth paragraph, have written that the President Joko Widodo had better prioritize the second period of his leadership to solve economic, improve public services, decrease inequality, and eradicate corruption. It appears that the journalists wanted the readers to refuse the government's plan since they were convinced that relocating the capital city was not the best solution for development planning equity and economic justice. The analysis of the microstructure level was begun with the strategy of discourse, such as semantics, syntactic, stylistics, and rhetorical levels. The analysis of news text found a tendency that the public was directed to provide a negative image of the government through a thematic, schematic, semantic, syntactic, stylistic, and rhetorical analysis of the text. Different from the previous research by Assidik and Santoso (2016), in which Fairclough's CDA was employed for analyzing Suara Merdeka and Republika newspaper about the image of the President (Joko Widodo), this study showed that textual analysis plays a role in investigating how the mass media portray the President.

Furthermore, in light of the study conducted by Todo and Budiarta (2018), it has some similarities to this study in terms of the design and object of the study. In their research, a model of Van Dijk's CDA was used to analyze daily newspaper reports on profiteering through the names of President Joko Widodo and Vice President Jusuf Kalla. The result showed that President Joko Widodo and Vice President Jusuf Kalla's names were only considered to delegitimize President and Vice President's authority and state institutions. The journalists' mental awareness is formed on the daily Kompas news text as a role scheme and event scheme. 
Meanwhile, the context of social influenced the discourse naming's formation, such as power and access.

However, it is essential to put together a serious definition to know the critical paradigm of mass media. Mass media research is more placed in the awareness that text or discourse in mass media influences humans. Eriyanto (2001) stated that the dominant group could control the media. It is because the media is not a neutral entity. Accordingly, media are means by which the dominant group can control non-dominant groups, even marginalizing them by controlling media. Therefore, the critical paradigm possessed by researchers in mass media research is a factor that influences the conduct of critical discourse analysis research, especially in analyzing the language used in the media (Fitri \& Manaf, 2019).

According to Van Djik (2008), the power and ideology of mass media can be intended to regulate individuals or members of a group. This is supported by the evidence from the findings that the power and ideology of tempo.com in the news persuade readers to reject the relocation of the capital city. Furthermore, the journalists encourage not to support the government's plan. The journalists went on to say that there are still many problems, such as equitable development and economic justice. Therefore, the relocation plan must be rejected because it is not the solution for equity and economic justice.

Also, it is different from a study by Martono and Mulyani (2018) addressing the power and ideology reflected in 2017 entitled "Critical discourse analysis towards authority ideology: Case of mega corruption E-KTP (electronic ID card)" in Tempo magazine. The result showed that the practice of power practice in the discourse on mega corruption was related to members of the People's Consultative Assembly and Constitutional Court chief justice. The chief justice abuses his power to reprimand the accused. Judging from the practice, power access can use and affects the discourse. Another research by Ibnus (2019) also addressed the power and ideology reflected in CNN Indonesia's discourse of the representation of the 212 "reunion" in Indonesia online media. The result showed that the power and ideology in CNN Indonesia were considered politically charged because it is more concerned about the adverse effect of the action. Simultaneously, Republika online media gives the humanist theme, but it does not deny the political aim behind the action. Furthermore, CNN Indonesia is more visible and attempts to convince the readers that the action was bad and oriented itself toward political purposes while Republika online news contains the good side of action and was more informative.

In the analysis of critical discourse, conversational and other texts formed from ideological practice or ideology, reflection and power were created only to perpetuate certain powers. The aim is none other than the manipulation of the ideology of the dominant group over the 
marginal group through a disinformation campaign, whether on religious, social, political, or other discourses. From the news text, we can see the dominance of nationalist groups towards readers who are still neutral or even against those who reject the government's plan. Tempo.com, in reporting "Tolak Relokasi Ibu Kota," seems to use the opportunity to practice its ideology to build a negative image of government performance. The results of this study were somewhat different from a research study by Putra and Triyono (2018). In their research, it addressed Gerakan \#2019GantiPresiden Between Legal Ambiguity and Political Passion text. The result showed that the \#2019GantiPresiden movement was considered as the movement of constitutional, which was indicated as a rebellion movement because it is supported by the political interests against the rivals of the current government. Therefore, it was also acceptable if kompas.com created a current positive government's image. The main information point conveyed in the \#2019GantiPresiden news was this movement might threaten the government of Jokowi Widodo, which will run again for the 2019 presidential elections.

Ultimately, the importance of this CDA was to raise awareness of readers that media and politics have a reciprocal relationship. In this sense, politicians communicate with the public through the news media, which they cannot control because the news media stands between politicians. To figure out how media and politics supported each other, it is necessary to reveal the findings in a more in-depth study. The existence of mass media is ultimately useful for helping readers and learners in learning the concept of CDA.

\section{CONCLUSION}

Conducted within critical discourse analysis, this present study provided information about the structure of the text. The findings suggested that the journalists of tempo.com media built public opinion in the news negatively. They utilized diction selection, cause-effect organization, and selected speaker's indirect quotations to produce news texts. The journalists seem to think that disapproval is the dominant responses and attitudes in society. This disapproval reminded the public not to support the relocating capital city. Also, the news was considered in harmony with its mission of providing a multimedia product that was independent and free from all pressures. The readers were led to a negative image of the government on tempo.com as an active and existent media in voicing justice. In the end, the community will be made to sharpen their sensitivity to society, culture, and politics.

Media practitioners should be critical in producing texts because seeing the texts produced contain discourses that might affect society. The production of media texts should be observant. 
By doing so, they could be social transformation to support clean and honest democratic practices. The discourse formed should not only be critical but also provide solutions so that the media can become a driving force and change in a positive direction. Besides, future researchers can do better research on other CDA studies and enlarge the research focus.

\section{REFERENCES}

Assidik, G. K., \& Santoso, B. W. J. (2016). Citra publik Presiden Republik Indonesia pada pemberitaan di Harian Suara Merdeka, Tabloid Tempo, dan Harian Republika: Kajian analisis wacana kritis model Norman Fairclough. Seloka : Jurnal Pendidikan Bahasa Dan Sastra Indonesia, 5(2), 201-215.

Eriyanto. (2001). Analisis wacana: Pengantar analisis teks media. Yogyakarta : LKiS.

Fairclough, N. (1995a). Critical discourse analysis: The critical study of language. Longman.

Fairclough, N. (1995b). Media discourse. Edward Arnold.

Fathan, D. (2018). Analisis wacana kritis berita "kematian terduga teroris Siyono" di Harian Solopos. Al-Balagh: Jurnal Dakwah Dan Komunikasi, 3(1), 45-72.

Fitriana, R. A., Gani, E., \& Ramadhan, S. (2019). Analisis wacana kritis berita online kasus penipuan travel umrah (model Teun a. Van Dijk). BASINDO : Jurnal Kajian Bahasa, Sastra Indonesia, Dan Pembelajarannya, 3(1), 44-54.

Hasanah, U., Alek, A., \& Hidayat, D. (2019). A critical discourse analysis of Kim Namjoon's (RM'S) speech. Jurnal Humaniora Teknologi, 5(2), 16-26.

Helfer, L. (2016). Media effects on politicians: An individual-level political agenda-setting experiment. The International Journal of Press/Politics, 21(2), 233-252.

Hidayah, S. A., \& Hidayat, D. N. (2019). An analysis of Russell Peters' humor discourse of stand-up comedy about Indian Doctors on YouTube. The 5 The International Conference on Education in Muslim Society (ICEMS), 118-124.

Kendall, G. (2007). What is critical discourse analysis? Ruth Wodak in conversation with Gavin Kendall. Forum Qualitative Sozialforschung / Forum: Qualitative Social Research, $8(2), 29$.

Leeuwen, T. V. (2008). Discourse and practice: New tools for critical discourse analysis. Oxford University Press.

Martono, M., \& Mulyani, S. (2018). Critical discourse analysis towards authority ideology "case of mega corruption E-KTP (electronic ID card)" in Tempo magazine. JETL (Journal of Education, Teaching and Learning), 3(1), 1-8.

Mills, S. (1992). Knowing your place: A Marxist feminist stylistic analysis. Routledge.

Nuraeni, R. (2017). Peran media sosial dalam tugas jurnalistik. Jurnal Ilmiah LISKI (Lingkar Studi Komunikasi), 3(1), 43-58.

O'Connor, H., \& Gibson, N. (2017). Step-by-step guide to qualitative data analysis. Pimatiziwin: A Journal of Aboriginal and Indigenous Community Health, 1(1), 64-90.

Putra, H. P., \& Triyono, S. (2018). Critical discourse analysis on Kompas.com news: "Gerakan \#2019Gantipresiden." LEKSEMA: Jurnal Bahasa Dan Sastra, 3(2), 113. https://doi.org/10.22515/ljbs.v3i2.1412 
Rahzanie, R. D., \& Rustono, R. (2019). The representation of media power in editorial languages on Pikiran Rakyat daily newspaper. Seloka: Jurnal Pendidikan Bahasa Dan Sastra Indonesia, 8(2), 39-47.

Setiawan, I. (2016). Morfem suprasegmental pada teks pidato pengunduran diri Prabowo-Hatta dalam Pilpres tahun 2014: Sebuah tinjauan fonologis. Jurnal Aksara, 28(1), 61-76.

Supriyadi, S., \& Zulaeha, I. (2017). Dimensi ekonomi, politik, dan ideologi pada artikel-artikel di media massa cetak Jawa Pos dalam perspektif analisis wacana kritis abstrak. Seloka: Jurnal Pendidikan Bahasa Dan Sastra Indonesia, 6(1), 1-14.

Todo, M. F. L., \& Budiarta, I. W. (2018). Critical discourse analysis on Kompas daily newspaper report on profiteering through the names of President Jokowi and Vice President Jusuf Kalla. RETORIKA: Jurnal Ilmu Bahasa, 4(1), 26-37.

van Dijk, T. A. (2008). Discourse and context: A sociocognitive approach. Cambridge University Press. 